\title{
State Guideline in Indonesia: How to Accommodate Based on The State System of Indonesia
}

\author{
Ratna Herawati ${ }^{1}$, Novira Maharani Sukma ${ }^{2}$ \\ \{ratna h27@yahoo.com ${ }^{1}$, noviramaharani@gmail.com $\left.{ }^{2}\right\}$ \\ ${ }^{1,2}$ Faculty of Law, Diponegoro University, Semarang, Indonesia
}

\begin{abstract}
State guideline is the direction for the state organizers. These guidelines can be federal, whether in the economic, cultural, or legal fields. The position of a guideline must be maintained consistently. The relevance and similarity between the values, rules and fundamental norms contained in UUD 1945 of the Republic of Indonesia with the formulation of a policy made by a state authority in a juridical format, in which the policy must be subject to higher provisions. After the reformation of UUD 1945 of the Republic of Indonesia, the guidelines had not existed due to the lack of State Policy. This condition has triggered the urgency of this research. There are two problems raised in this research: (1) Has Indonesia accommodated the state guideline in the constitution?; and (2) How is the state guideline that is compatible with the state system of Indonesia? The problems are analyzed using Post-positivism paradigm with different approaches, namely legislation, conceptual, and comparative in the study of the existing literature. Technique of checking the accuracy of the data in this research used triangulation method. The findings obtained: (1) Indonesia has accommodated the state guideline in the constitution, and (2) The state guideline by the state system of Indonesia is as defined in the Rencana Pembangunan Jangka Panjang Nasional (RPJP) (National Long Term Development Plan)
\end{abstract}

Keyword: State Guideline, Presidential System, Constitution of the Republic of Indonesia

\section{Introduction}

Prior to the Undang-Undang Dasar/Constitution (hereinafter referred to as UUD 1945), amendments shall be mandated, mandating the Majelis Permusyawaratan Rakyat/People's Consultative Assembly (hereinafter referred to as the MPR) to formulate a broad outline of the state guidelines (hereinafter referred to as GBHN) under Article 3 of UUD 1945. GBHN is discussed once every five years by all members of MPR representing all Indonesians. This is because UUD 1945 embraces the supremacy of the MPR. Also, UUD 1945, in Article 6 paragraph (2) states that MPR shall elect the President and Vice President based on the majority vote. The elected president is accountable to the MPR in running the government. Thus the president must run the state policy according to the GBHN set by the MPR.

GBHN outlines policies, steps, and targets as guidelines for the preparation of national development plans to realize the national ideals contained in the preamble of UUD 1945 and the articles of UUD 1945. However, based on UUD 1945 of the Republic of Indonesia (UUD after the amendment), the article is amended and revokes the MPR's authority to formulate the GBHN [1]. It is considered since the presidential election system is directly elected by the people so that it has a direct responsibility to the people. 
Physically, GBHN has indeed been eliminated in the national development system, but the spirit of national development which previously stipulated in GBHN remains the foundation of the government in organizing the wheels of government. This can be seen in the consideration of Law Number 17 Year 2007 on the National Long Term Development Plan of 2005-2025, in the weighing dictum stating that the amendment of UUD 1945 has resulted in changes in the management of development, i.e. by no longer made GBHN as a guide for the preparation of the National development plan. Furthermore, it is mentioned that Indonesia needs long-term development planning as the overall direction and priority of development which will be done gradually to create a just and prosperous society as mandated by UUD 1945 of the Republic of Indonesia (from now on referred to as UUD 1945 of the Republic of Indonesia).

In terms of nomenclature, the naming of GBHN with the law (hereinafter referred to as UU/the Law) is two different things. But when viewed in terms of the content between the Law and GBHN, the substance contained between the two have similarities in determining the direction of national development, it is then just put in the form of law. Therefore, bringing back the state policy (in this case, GBHN) is not without problems.

On the other hand, there is a basic idea related to the reimplementation of GBHN. There is an assumption that RPJP and RPJM prepared by the government establish a process of development that is not measurable and directed so as not yet able to improve the welfare of the nation, therefore a clear direction is needed in achieving the goals of development through the re-implementation of the state policy.

Based on the above matters, then the problems in this study are: (1) Has Indonesia accommodated the state guideline in the constitution?; and (2) How is the state guideline that is compatible with the state system of Indonesia?

\section{Methodology}

The problems are analyzed using Post-positivism paradigm with different approaches, namely legislation, conceptual, and comparative in the study of the existing literature. The technique of checking the accuracy of the data in this research used the triangulation method.

\section{Literature Review}

This research uses literature about state guideline. State guideline before UUD 1945 amended is named GBHN but after amended is named SPPN. State guideline based on the ideology of Indonesia. The ideology of Indonesia based on Five Pillar (called Pancasila) are listed in preamble of UUD 1945.

The other literature is the presidential system. Presidential system before and after an amendment is different. After amendment Presidential System is confirmed.Last literature is The Constitution of Republik Indonesia. This point about checks and balances system, i.e., checks and balances between the executive and legislative branch. 


\section{Findings}

\subsection{State Guideline in Indonesia}

The idea of restoring GBHN is a step back in strengthening presidential and democratic systems. It is because in democracies, a majority of the people determines policy either by directly voting on issues and democratic mechanisms serve to limit the divergence between the actions of political officials and the preferences of the people [2]. However, it must be remembered that Indonesia is based on Pancasila (The Five Pillars) democracy, the system of decision-making in the implementation of democracy is stressed by the concept of deliberation and consensus which is derived from the original order of Indonesia.

Pancasila is a value. Pancasila to be the norm then listed in preamble of UUD 1945. Thus the actual guideline for Indonesia is in preamble UUD 1945. This preamble was described in the article in UUD 1945.

GBHN is in a vast potential of putting MPR back as the highest state institution. If that happens, then the consequences of the presidential accountability system are no longer to the people but the MPR. This condition will be challenging for the elected president in realizing the goals of the state and implement the vision and mission promised during the presidential election campaign. In addition, if the state takes the path to amend UUD 1945 of the Republic of Indonesia as a form of compromise to legalize GBHN in the constitution of the state, then what happens is a very significant change in the system of government, the relationship between state institutions, to the duties and functions of state institutions.

The Indonesian presidential government system in which the president is no longer accountable to MPR and cannot be dismissed by MPR, but directly to the people is because presidential and vice-presidential are elected through general elections. The electoral system is at the very heart of democratic representation [3]. In his position as a representation of the people, the president has a vital role in determining the direction of national development. Without a directed development, it is impossible for the country's objectives stated in the fourth paragraph of the Preamble of UUD 1945 of the Republic of Indonesia can be achieved.

The amendment process of UUD 1945 from 1999 to 2002 has five commitments agreed upon by the ad-hoc committee of the MPR RI. The five commitments are not changing the preamble of UUD 1945, maintaining the Unitary State of the Republic of Indonesia, abolishing the explanation of UUD 1945, an addendum amends UUD 1945, and the last is reinforcing the presidential government system.

The basic agreement to enforce a presidential government system is intended to strengthen a stable and democratic system of government. This is one of the corrective actions against the prior presidential system before UUD 1945 is amended. The old system created many weaknesses in the implementation of checks and balances system. The system of checks and balances is based on a distrust of majority ruling and a strong preference for internal or inter-branch controls, rather than external or accessible controls [4].

The presidential system has some unique characteristics that distinguish it from the parliamentary system of government. Characteristic from the parliamentary system: the legislature choose the executive and the cabinet; the legislative majority can remove the executive before her terms are up through a no-confidence vote; and if legislators vote to remove the executive, the legislature also may dissolve, and a new election may be called [5]. However, the presidential system is the president, and his cabinet is not accountable to the legislature, but directly to the people [6]. The president is responsible and accountable 
for the executive branch and has the power to appoint and dismiss his cabinet without the approval of legislative.

During the four changes of amandment UUD 1945 (1999-2002), various ways to emphasize the presidential government system in Indonesia:

1. Change the process of president and vice president election from the election with the representative system (electoral mechanism in MPR) to direct election, so the president and vice president not a responsibility to MPR;

2. Limiting the official period of president/vice president that is for five years and after that may be re-elected as much as one time;

3. Clarify the mechanism of impeachment of the President and Vice President;

4. Prohibition for the President to dissolve the DPR;

5. Renew the law testing mechanism;

Since GBHN is absent, there established the Law Number 25 the Year 2004 on National Development Planning System which regulates the description of the goals and ideals of the Indonesian nation as contained in the Preamble of UUD 1945, outlined in the form of Long Term Development Plan (from now on called RPJP). The validity period is 20 years. To carry out all the plans in the RPJP, they need to be implemented gradually within five years so that the Medium Term Development Plan (from now on referred to as RPJM) is made. Thus the state policy in the Indonesian Constitution is explicitly not contained in the article of UUD 1945 of the Republic of Indonesia. However, if it is based on the legal basis in Law No. 25 Year 2004 on National Development Planning System as stated in the recall section, that are Article 18, Article 18A, Article 18B, Article 20, Article 20A, Article 21, Article 23, Article 23C, Article 33, Article 34, then it indirectly appoints the articles of UUD 1945 of the Republic of Indonesia.

The vision, mission, and development program of the elected President is contained in RPJM, but it still refers to RPJP. The objectives to be achieved by the enactment of the Law on National RPJP 2005 - 2025 are to (a) support the coordination among development actors in the achievement of national objectives, (b) ensure the creation of integration, synchronization, and synergy, either inter regions, space, time, government functions as well as between Central and Local level (c) ensure the linkages and consistency between planning, budgeting, implementation and supervisory, (d) ensure the efficient, effective, equitable and sustainable use of resources; and (e) optimizing community participation.

In the local level, RPJP and RPJM are prepared by the local government in keeping with the national RPJP. If we look at this matter, then the legal form for what was formerly called GBHN is now changed into law, made by People's Representative Council (DPR), namely Law Number 25 the Year 2004 on National Development Planning System is the same. The difference is only by the name, which is no longer GBHN, but RPJP. The former functions played by GBHN have been realized more comprehensively in the Law of the National Development Planning System Year 2004 and the Law of Long Term Development Plan Year 2007.

Based on the statements above, the substance of GBHN has been accommodated in the Law on National Development Planning System (from now on referred to as SPPN); thus, there is no need for GBHN. The President's vision follows the State's objective, thus it gives the President the chance to realize his promises stated in his campaign that the people have agreed to by choosing him directly, and by implementing the programs through his five-year development program. Medium-term development contains the promise of the elected President to carry out his mission of conducting the development and determining 
development priorities based on the State objectives and the ideals of the proclamation formulated in the Preamble to UUD 1945 embodied in the RPJP.

\subsection{State Guideline based on the State System of Indonesia}

The substance of the state policy, in this case, as previously stated in the GBHN, has been accommodated in the SPPN Law. GBHN established by the People's Consultative Assembly of the Republic of Indonesia (MPR RI) serves as the foundation of national development planning as has been implemented in the practice of state administration so far. The Decree of MPR RI becomes the legal basis for the President to be elaborated in the form of the Five Year Development Plan by taking seriously the advice of the House of Representatives of the Republic of Indonesia (DPR RI), which then the Government together with DPR RI draft the State Budget. With the amendment of UUD 1945 of the Republic of Indonesia which regulates that the President is directly elected by the people [7] and the absence of the GBHN as the President's guidance to formulate the development plan, then it will require further regulation of the National Development Planning process, which is then stipulated in the SPPN Law.

There are three strong points of SPPN that are not owned by GBHN. First, SPPN is more focused because the planning and implementation of supervision are under one command line, which is by the executive or president. Based on that, the SPPN will be undoubtedly more focused and easy to implement because it is only held by one institution. Furthermore, this will facilitate the coordination because starting from planning until the implementation level; the President holds they all as a branch of power that has full authority in implementing development. It also seemed to imply that all other legitimate authority was implicitly or explicitly authorized by the power of the state [8]. This is what makes SPPN is by presidential system practice in Indonesia because the President is the one who is given the authority to determine the direction of national development policy, not MPR.

On the other hand, GBHN has triggered the discontinuity between the expected program and the realized program, because the process of planning is in the MPR while its implementation is in the President. This will undoubtedly make the President feel uncomfortable because the program which will be implemented is not by what is believed. Although the President has authority to the realized program based on SPPN Law, DPR can limit this power using the monitoring function.

The power of limitation through the power of separation and division gives more description of the clarity of the position of each branch of the state authority in performing its constitutional functions. Meanwhile, the checks and balances give more emphasis on efforts to establish balanced mechanisms for mutual control among branches of state power. Thus, the checks and balances are among the branches of power, namely legislative, executive and judicial. The relations between the three branches: legislative, executive, and judicial, are relations of cooperation that literature calls checks and balances, meaning, their mutual supervision to rebalance the relationship between them [9].

Second, in SPPN, there is a mechanism called Musrenbang or Development Planning Deliberation, which consists of elements of state organizers, academics, and community. That means SPPN is based on a qualified practice and academic study because it involves many parties in planning, although, in the end, the final plan is in the hands of the President. Meanwhile, GBHN preparation is only done by the MPR on its own, without the participation of other elements that have considered as well. This, of course, resulted in the planning process of GBHN to contain only political elements, unlike SPPN, which has 
many contents of practical and academic needs. This is in line with democracy in Indonesia. The system of decision-making in the implementation of democracy is stressed by the concept of deliberation and consensus, which is derived from the original order of Indonesia. It must be remembered that the political equality principle among the citizens is the characteristic of a democratic state [10], which in Indonesia it is based on Pancasila (The Five Pillars).

Third, SPPN brings the spirit of regional autonomy. The Republic of Indonesia is a unitary state. A unitary state is a form of the state in which the highest legislative authority/concentration is at the national legislative/central. Indonesia is based on the principle of decentralization in the administration of government by providing opportunities and flexibility to regions to organize regional autonomy. Decentralization was intended to promote local democracy and administrative efficiency, not to challenge the underlying principles of unitary state [11]. Regional autonomy is the right authority and obligation possessed by the autonomous regions to regulate and manage their governmental affairs and the interests of the community in its territory based on the principle of decentralization that remains within the framework of the unitary state of the Republic of Indonesia. Regional autonomy in Indonesia is organized in order to improve people's welfare.

The local government can adjust the development of a region by considering the potential and uniqueness of each region. Local Government (consist of the governor and DPRD) are elected through the general election. Local Government knows the state of the local community. Multilevel governance has played an essential part in mediating relations of the civil society [12]. Implementation of regional autonomy, aside from based on the applicable law, it is also an implementation of the demands of globalization that is empowered by giving the region a broader, more real, and responsible authority, especially in regulating, utilizing and exploring the potential sources in their respective areas. The better or worse of an area is determined by the ability and willingness to carry out local governance. Local governments are free to create and express themselves in determining the direction of regional development planning as contained in the form of Regional Medium Term Development Plan (from now on referred to as RPJMD).

With the SPPN format consisting of RPJMD, it makes local governments can freely undertake development planning according to the empirical needs in the region. It is because basically no one knows better the development needs in a region than the local community itself and the local government. Whereas in GBHN, which only consists of one planning document, it makes the region forced to submit to development planning owned by the Central Government. This is because the preparation of GBHN is centralistic and Top-Down, which increases the potential of un-accommodated different special needs in various regions because all development planning throughout the territory of Indonesia is generalized by the Central Government through GBHN.

Also, if later GBHN is a product of MPR, in the sense of being followed up in the MPR Decree, then it is not by Law Number 11 the Year 2011 on the Regulatory Sequence of Law. The explanation of the law in Article 7 paragraph 1 sub-paragraph $b$ that the MPR's decision is the MPRS decision and the current MPR Decree is as referred to in Article 2 and Article 4 of MPR Decree No. I/MPR/2003 on Review of Material and Legal Status of MPRS Decree and MPR Decree Year 1960-2002, dated on 7 August 2003.

After amandment UUD 1945, MPR has not been authorized to make TAP MPR. So, if there is GBHN as the product of MPR using TAP MPR, then the question is how the binding force of the parties in the GBHN. 
As mentioned above, the normative construction of RPJP is substantially similar to GBHN during the New Order (Orde Baru) period. Additional value that RPJP possesses is the opportunity for the regions to be able to explore the potentials and strong points of their respective regions, to synergize with the "master plan" contained in the RPJP in order to achieve the goals mandated by the constitution. The urgency to revive GBHN is not justified since its existence has been realized in RPJPN. Thus, instead of reinventing GBHN, it is better to improve the Long Term Development Plan (RPJP) within the level of the Law (UU).

As a subject of contemplation so that the SPPN run consistently, then it should do the following:

1. President has to continue the program based on RPJP and RPJM. If the President does not carry it out, it could lead to the mechanism of impeachment.

2. Local Government must support and has a particular thought that Indonesia is a unitary state. The regional development planning as contained in the RPJMD based on RPJM and RPJP.

3. The good faith of all components of the Indonesia nation to realize the ideals of the nations, as stated in the preamble of UUD 1945.

\section{Conclusion}

The conclusion in this paper about the State Guideline has been accommodated in the Constitution of Indonesia (UUD 1945 of the Republic of Indonesia) because it contains fundamental principles as a guiding principle in describing the state philosophy and the articles of the Constitution into various laws and development policies in all fields and layers.

Besides, state guideline in the state system of Indonesia not legalizing GBHN in the constitution is due to a very significant change in the system of government, the relationship between state institutions, to the duties and functions of state institutions. The state guideline by the state system of Indonesia is accommodated in preamble UUD 1945. There established the Law Number 25 the Year 2004 on National Development Planning System which regulates the description of the goals and ideals of the Indonesian nation as contained in the Preamble of UUD 1945. This preamble was described in the article in UUD 1945.

\section{References}

[1] M. Budiardjo, Dasar-Dasar Ilmu Politik. Jakarta: Gramedia Pustaka Utama, 2008.

[2] P. Moser, The impact of legislative institutions on public policy: a survey vol. 15. 1999.

[3] K. Dunn, "Voice, and trust in parliamentary representation," Elect. Stud, vol. 31, no. 2, pp. 393-405, 2012.

[4] R. Gargarella, We the People Outside of the Constitution: The Dialogic Model of Constitutionalism and the System of Checks and Balances. 2014.

[5] J. Vandusky-Allen, "Winners, losers, and protest behavior in parliamentary systems," Soc. Sci. J., vol. 54, no. 1, pp. 30-38, 2017.

[6] D. M. Aritonang, Penerapan Sistem Presidensil di Indonesia Pasca Amandemen UUD 1945. 2004.

[7] A. H. . Chen, "Pathways of western liberal constitutional development in Asia: A 
comparative study of five major nations," Int. J. Const. Law, vol. 8, no. 4, pp. 849884, 2010.

[8] R. Nikolas, Powers of Freedom, Reframing Political Thought. 2004.

[9] O. . Nicoleta, "Relations Between the Parliament and the Government in the Romanian Constitutional," Law Procedia - Soc. Behav. Sci., vol. 81, pp. 246-249, 2013.

[10] B. . Anggono, "The Tenure Arrangement of Primary Constitutional Organ Leaders in Indonesian Constitutional System," Const. Rev., vol. 2, no. 1, p. 51, 2016.

[11] J. Cole, A; Loughlin, Beyond the Unitary State? Public Opinion Political Institutions and Public Policy in Brittany. 2017.

[12] S. Arora-Jonsson, "The realm of freedom in new rural governance: Micro-politics of democracy in Sweden," Geoforum, vol. 79, pp. 58-69, 2017. 